\title{
FAKTOR- FAKTOR YANG MEMPENGARUHI PROSESPELAKSANAAN PEKERJAAN JALAN LINGKAR KOTA KENDARI II
}

\author{
La Madu ${ }^{1}$, Sunaryo ${ }^{2}$, Laoede Musa Rachmat ${ }^{3}$ \\ ${ }^{1}$ Nama Prodi, Fakultas, Universitas Sulawesi Tenggara \\ email: lamadu14@gmail.com \\ ${ }^{2}$ Nama Prodi, Fakultas, Universitas Sulawesi Tenggara \\ email: sunaryo123@gmail.com \\ ${ }^{3}$ Nama Prodi, Fakultas, Universitas Sulawesi Tenggara \\ email: musarachnat@yahoo.com
}

\begin{abstract}
Project delays can come from service providers or other users who have an impact on additional time and expenses beyond the plan. If the delay comes from the contractor (Contractor), the contractor may be fined, as well as if the delay arises from the user of the service, the service user shall pay the loss incurred by the service provider, the amount stipulated in the contract in accordance with applicable legislation. Many studies have been done to determine the factors that cause the delay in completion of the project.

Budgeted Cost of Work Scheduled (BCWS), describes the budget plan to a certain period of volume of the project plan to be done. Budgeted Cost of Work Performed (BCWP), describes the project plan budget for a certain period of what has been done on the actual volume of work.

Land acquisition is the work of Kendari II railway project, at the time of execution of work there is a name of compensation made from the government to the community, if there is a community land whose land is affected by the project. The availability of budget is Kendari II road project, with length $38.15 \mathrm{~km}$ with budget amount Rp. 2.607.981.000,00 this is very limited. So that the contractor to carry out the project work according to the existing volume. Geographical conditions of the work of Kendari II city circle project, there are drawings of plans and work items before carrying out a project work. This research concludes that factors influencing the completion of construction project of Kendari II ring road.

In accordance with the calculation of SPSS program (factor analysis) of 3 factors that affect the process of execution road construction project in Kendari City. The 3 factors that are contribution value in detail are: 1) availability of budget with value 93,3\%,2) land acquisition with value 68,5\% and 3) Geographical condition with value $61,8 \%$.
\end{abstract}

Keywords: Land Acquisition, Budget Cost, Geographical Condition

\section{ABSTRAK}

Keterlambatan proyek bisa berasal dari penyedia jasa pengguna jasa maupun pihak lain yang berdampak penambahan waktu dan biaya diluar rencana. Bila keterlambatan berasal dari kontraktor (Penyedia jasa), maka kontraktor bisa dikenai denda, begitu juga bila keterlambatan berasal dari pengguna jasa, maka pengguna jasa akan membayar kerugian yang ditanggung penyedia jasa, yang jumlahnya ditetapkan dalam kontrak sesuai perundang- undangan yang berlaku. Banyak penelitian yang sudah dilakukan untuk mengetahui faktor-faktor penyebab keterlambatan penyelesaianproyek .

Budgeted Cost of Work Scheduled ( BCWS ), menggambarkan anggaran rencana sampai pada periode tertentu terhadap volume rencana proyek yang akan dikerjakan.Budgeted Cost of Work Performed ( BCWP ), menggambarkan anggaran rencana proyek pada periode tertentu terhadap apa yang telah dikerjakan pada volume pekerjaan aktual.

Pembebasan lahan yaitu Pekerjaan proyek jalan lingkar kota kendari II, pada saat pelaksanaan pekerjaan ada namanya ganti rugi yang dilakukan dari pihak pemerintah kepada masyarakat, apabila ada lahan masyarakat yang lahannya terkena proyek tersebut. Ketersediaan anggaran yaitu Pekerjaan proyek jalan lingkar kota kendari II,dengan panjang 38,15 km dengan jumlah anggaran Rp. 2.607.981.000,00 hal ini sangat terbatas. Sehingga pihak kontraktor melaksanakan pekerjaan proyek sesuai volume yang ada.Kondisi geografis yaitu Pekerjaan proyek jalan 
lingkar kota kendari II, ada gambar rencana dan item-item pekerjaan sebelum melaksanakan suatu pekerjaan proyek tersebut.

Penelitian ini menyimpulkan bahwa faktor yang mempengaruhi proses penyelesaian proyek konstruksi jalan lingkar Kota Kendari II. Sesuai dengan hasil perhitungan program SPSS (analisis faktor) dari 3 faktor yang mempengaruhi proses pelaksanaan proyek konstruksi jalan di Kota Kendari. Adapun ke-3 faktor yang di teliti nilai kontribusi adalah : 1) ketersediaan anggaran dengan nilai 93,3\%, 2) pembebasan lahan dengan nilai 68,5\% dan 3) Kondisi geografis dengan nilai $61,8 \%$.

Kata kunci : Pembebasan lahan, Anggaran Biaya, Kondisi Geografis

\section{PENDAHULUAN}

Pembangunan infrastruktur merupakan program pemerintahan masa kini yang selalu di genjot setiap saat untuk menunjang perekonomian bangsa dan negarasehingaga dapat menjadikan masyarakat yang sejehtera dan mandiri. Dalam pembangunan infrastruktur juga selalu mengalami kendala dalam pelaksanaannya baik itu masalah teknis maupun non teknis. Pembangunan infrastruktur tentu selalu melalui proses atau mekanisme yang sudah diatur dalam undang-undang pengadaan barang/jasa sehingga dalam prosesnya dibutuhkan dokumendokumen yang menjadi persyaratannya dan disebut dokumenpengadaan. Dokumen pengadaan adalah dokumen yang ditetapkan oleh kelompok kerja yang memuat informasi dan ketentuan yang ditaati oleh para pihak dalam proses pengadaan (PERPES NO. 14/2015).

Untuk mensinergikan program pemerintah pusat dan pemerintah daerah dalam pembangunan infrastruktur maka pemerintah Provinsi Sulawesi Tenggara juga menggenjot pembangunan infrastruktur diantaranya adalah Jalan dan Jembatan untuk menghubungkan antara satu wilayah ke wilayah yang lain sehingga memudahkan akses buat masyarakat di wilayah tersebut, juga sebagai salah satu upayahpemerintah untuk medorong perekonomian masyarakat baik secara khusus maupun secara umum.

Namun dalam pelaksanaan

Keterlambatan proyek bisa berasal dari penyedia jasa pengguna jasa maupun pihak lain yang berdampak penambahan waktu dan biaya diluar rencana. Bila keterlambatan berasal dari kontraktor (Penyedia jasa), maka kontraktor bisa dikenai denda, begitu juga bila keterlambatan berasal dari pengguna jasa, maka pengguna jasa akan membayar kerugian yang ditanggung penyedia jasa, yang jumlahnya ditetapkan dalam kontrak sesuai perundang- undangan yang berlaku. Banyak penelitian yang sudah dilakukan untuk mengetahui faktorfaktor penyebab keterlambatan penyelesaianproyek .

Berdasarkan data base jalan provinsi, pelaksanaan jalan lingkar kota Kendaridengan panjang $38,15 \mathrm{~km}$ yang dalam pelaksanaanya bertahap dan fokus pada jalan lingkar kota Kendari II dengan anggaran $\mathrm{Rp}$ 2.607.981.000,-. Dalampelaksanaanya dan kondisinyatidak jauh berbeda dengan proyek-proyekkonstruksi yang lain. Ada beberapa hal yang mempengaruhi proses penyelesaian proyek, diantaranya pembebasan lahan pada saat pelaksanaan pekerjaan, masalah keterbatasan anggaran, keadaan geografis, dan lain sebagainya yang sering sekali dinggap tidak berpengaruh dalam proses penyelesaian proyek tersebut 
kendatipun pembebasan lahan, keterbatasan anggaran dan keadaan geografis sudah ada tim yang dibentuk yang akan menanganinya namun tetap saja menjadi suatu masalah, sehubungan dengan itu ada beberapa hal / permasalahan - permasalahan yang penting dan perlu diketahui serta diteliti. Berdasarkan permasalahan tersebut penulis akan mengangkat sebuah Skripsi yang mengkaji masalah masalah proses pelaksanaan sehingga penulis mengangkat sebuah judul "Faktor-Faktor Yang Mempengaruhi Proses Pelaksanaan Pekerjaan Jalan Provinsi Studi Kasus Ruas Jalan Lingkar Kota Kendari II" dengan judul ini agar nantinya dapat menjadi pertimbangan pada pelaksanaan proyek untuk lebih menperhatikan masalah Pelaksanaan dalam mengerjakan proyek-proyek selanjutnya agar tidak mengalami keterlambatan.

Tujuan penelitian ini adalah sebagai berikut:

1. Menganalisa pengaruh proses pembebasan lahan, ketersediaan anggaran dan kondisi geografis padapenyelesaian proyek Jalan Lingkar Kota Kendari II.

2. Menganalisa peringkat(ranking) dari proses pembebasan lahan, ketersediaan anggaran dan kondisi geografis dalam penyelesaian proyek Jalan Lingkar Kota Kendari II.

\section{TINJAUAN PUSTAKA}

\section{A. Pengertian Penyedia Jasa}

Undang-undang Republik IndonesiaNo. 2 tahun 2017 tentangjasa konstruksimenyebutkan bahwa penyedia jasa adalah orang perseorangan/badan yang kegiatan usahanya adalah menyediakan layanan jasa konstruksi, yang terdiri dari konsultan perencana, konsultan pengawas, dan kontraktor. Pengertian dari masing- masing penyedia jasa akan dijelaskan sebagai berikut ini:

1. Konsultan perencana adalah penyedia jasa orang/badan usaha yang dinyatakan ahli yang profesional dibidang perencanaan jasa konstruksi yang mampu mewujudkan pekerjaan dalam bentuk dokumen perencanaan bangunan atau bentuk lain.

2. Konsultan pengawas adalah penyedia jasa orang/badan usaha yang dinyatakan ahli yang profesional dibidang pengawasan jasa konstruksi yang mampu melaksanakan pekerjaan pengawasan sejak awal pekerjaan sampai dengan selesainya pekerjaan.

3. Kontraktor adalah penyedia jasa orang/badan usaha yang dinyatakan ahli yang profesional dibidang pelaksanaan jasa konstruksi yang mampu menyelenggarakan kegiatan untuk mewujudkan suatu hasil perencanaan menjadi bentuk bangunan atau bentuk fisik lainnya.

\section{B. Keterlambatan Proyek}

Keterlambatan proyek (construction delay) diartikan sebagai penundaan penyelesaian pekerjaan sesuai kontrak kerja dimana secara hukum melibatkan beberapa situasi yang menyebabkan timbulnya klaim. Keterlambatan proyek timbul ketika kontraktor tidak dapat menyelesaikan proyek sesuai dengan waktu yang tercantum dalam kontrak (Ariful Bakhtiyar etal. 2012). Menurut Andietal, 2003 dalam penelitian I.A. Rai Widhiawati faktorfaktor yang potensial untuk mempengaruhi waktu pelaksanaan konstruksi, yang terdiri dari tujuh (7) kategori (Andietal. 2003), adalah :

1. Tenaga Kerja (labors):

a. Keahlian tenaga kerja.

b. Kedisiplinan tenaga kerja.

c. Motivasi kerja para pekerja. 
d. Angka ketidakhadiran.

e. Ketersediaan tenaga kerja.

f. Penggantian tenaga kerja baru.

g. Komunikasi antara tenaga kerja dan badan pembimbing

2. Bahan (material) :

a. Pengiriman bahan.

b. Ketersediaan bahan.

c. Kualitas bahan.

3. Peralatan (equipment):

a. Ketersediaan peralatan.

b. Kualitas peralatan.

4. Karakteristik Tempat (site characteristic):

a. Keadaan permukaan dan dibawah permukaan tanah.

b. Penglihatan atau tanggapan lingkungan sekitar.

c. Karakteristik fisik bangunan sekitar lokasi proyek.

d. Tempat

penyimpanan

bahan/material.

e. Akses ke lokasi proyek.

f. Kebutuhan ruang kerja.

g. Lokasi proyek.

5. Manajerial (managerial) :

a. Pengawasan proyek.

b. Kualitas pengontrolan pekerjaan.

c. Pengalaman manajer lapangan.

d. Perhitungan keperluan material.

e. Perubahan desain.

f. Komunikasi antara konsultan dan kontraktor.

g. Komunikasi antara kontraktor dan pemilik.

h. Jadwal pengiriman material dan peralatan.

i. Jadwal pekerjaan yang harus diselesaikan.

j. Persiapan/penetapan rancangan tempat.

6. Keuangan (financial) :

a. Pembayaran oleh pemilik.

b. Harga material.

Faktor - faktor lainnya (other factors) a. Intensitas curah hujan.

b. Kondisi ekonomi.

c. Kecelakaan kerja.

Jenis - jenis proyek menurut akifitas yang paling dominan dilakukan pada sebuah proyek, dikategorikan sebagai berikut :

a) Proyek engineering konstruksi, aktifitas utama terdiri dari pengkajian, desain engineering, pengadaan dan konstruksi.

b) Proyek engineering manufaktur, aktifitas utama adalah menghasilkan produk baru. Proyek manufaktur juga merupakan proses untuk menghasilkan produk baru.

c) Proyek pelanyanan manajemen, aktifitas utama merancang sistem, merancang program efisiensi, penghematan, diversifikasi, penggabungan dan pengambilalihan, memberi bantuan emergency untuk daerah yang terkena musibah, merancang strategi untuk mengurangi kriminalitas dan penggunaan obat obatan terlarang dan lain - lain.

d) Proyek penelitian dan pengembangan, aktifitas utama adalah melakukan penelitian dan pengembangan suatu produk tertentu.

e) Proyek kapital, biasanya digunakan oleh sebuah badan usaha atau pemerintah seperti pembebasan lahan dan lain - lain. Satu jenis proyek yang memiliki beberapa aktifitas sekaligus, maka pembagian jenis proyek adalah merupakan kombinasi. ( Nurhayati, 2010 ).

\section{Proses manajemen}

Menurut A.Daustendan R.H Neale (2001) dalam Suyatno 2010, yang dimaksud dengan proses manajemen adalah suatu proses untuk memanfaatkan sumber daya manusia 
dan sumberdaya lainnya untuk mencapai tujuan tertentu. Manajemen tergantung pada komunikasi yang jelas, dan kemampuan untuk melontorkan pemikiran, gagasan, informasi serta instruksi dengan cepat dan efektif diantara orangorang yang keterampilan teknis dan minatnya berbeda-beda. Proses manajemen atau seringjuga disebut Fungsi Manajemen, dalam satu kesatuan sebagai berikut dibawah ini:

1. Penempatan tujuan (goal setting) tujuan merupakan tahapan awal dari proses manajemen. Tujuan merupakan misi sasaran yang akantercapai.

2. Perencanaan (planning)merupakan proses pemilihan informasi dan pembuatan asumsi-asumsi mengenai keadaan dimasa yang akan datang untuk merumuskan kegiatan- kegiatan yang perlu dilakukan dalam rangka pencapaian tujuan yang telah ditetapkan sebelumnya.

3. Kepegawaian (Staffing)adalah proses manajemen yangberkenaan denganpengerahan(recruitment),

penempatan, pelatihan dan pengembangan tenaga kerja dalam organisasi. Pada dasarnya prinsip dari tahapan proses manajemen itu adalah menempatkan orang yang sesuai pada tempat yang sesuai dan pas pada saat yang tepat (right people, right position, right time).

4. Directing adalah usaha untuk memobilisasi sumber-sumber daya yang dimiliki oleh organisasi agar dapat bergerak dalam satu kesatuan yang sesuai dengan rencana yang telah dibuat. Dalam tahapan proses ini terkandung usaha- usaha bagaimana memotivasi orang- orang agar dapat bekerja.

5. Supervising didefinisikan sebagai interaksi langsung antara individu- individu dalam suatu organisasi untuk mencapai kinerja kerja serta tujuan organisas i tersebut.

6. Pengendalian (Controlling) yaitu panduan atau aturan untuk melaksanakan aktifitas suatu usaha atau bagian- bagian lain dari usaha tersebut untuk tercapainya tujuan yang telah disepakati.

\section{Kegiatan Proyek}

Operasi lapangan Tahap persiapan penggunaan bertujuan menjamin agar bangunan yang telah selesai dibangun sesuai dokumen kontrak, dan semua fasilitas bekerja Menurut Imam Soeharto ( 2002) dalam Suyatno 2010, suatu rangkaian kegiatan dapat dibedakan atas dua jenis, yaitu kegiatan rutin dan kegiatan proyek. Kegiatan rutin adalah suatu kegiatan terus menerus yang berulang dan berlangsung lama, sedangkan kegiatan proyek adalah suatu rangkaian kegiatan yang hanya satu kali dilaksanakan dan umumnya berlangsung dalam jangka waktu yang pendek. Oleh karena itu, suatu kegiatan proyek mempunyai awal dan akhir kegiatan yang jelas serta hasil kegiatan yang bersifat unik.

Dengan demikian dapat disimpulkan bahwa kegiatan proyek merupakansuatu rangkaian kegiatan yang mempunyai cirri-ciri sebagai berikut ini :

1. Dimulai dari awal proyek (awal rangkaian kegiatan) dan diakhiri dengan akhirproyek (akhir rangkaian kegiatan), serta mempunyai jangka waktu yang terbatas.

2. Rangkaian kegiatan proyek hanya satu kali sehingga menghasilkan produk yang bersifat unik. Jadi tidak ada dua atau lebih proyek yang 
identik, yang ada adalah proyek yang sejenis.

\section{E. Tahapan Proyek}

Menurut A.Daustendan R.H

Neale (2001)dalam Suyatno

2010, tahapan utama proyek

konstruksi terdiri dari 5 tahap, yaitu :

1. Tahap brifing bertujuan

memungkinkan klien menjelaskan

fungsi proyek dan biaya yang diijinkan, sehingga para arsitek, insinyur, surveyor kuantitas dan anggota lain kelompok perancang dapat secara tepat menafsirkan keinginannya dan menafsirkan biaya. Yang harus dilakukan selama tahap brifing adalah :

a) Menyusun rencana kerja dan menunjuk para perancang dan ahli;

b) Mempertimbangkan kebutuhan pemakai, keadaan lokasi dan lapangan, merencanakan rancangan, taksiran biaya, persyaratan mutu :

c) Mempersiapkan : Program data departemen, program data ruangan, jadwal waktu, sketsa yang menggambarkan denah dan batas-batas proyek, taksiran biaya dan rencana pelaksanaan.

2. Tahap perencanaan dan perancangan bertujuan untuk melengkapi penjelasan proyek dan menentukan tata letak, rancangan, metode konstruksi dan taksiran biaya agar mendapat persetujuan yang perlu dari klien dan pihak berwenang yang terlibat. Kegiatan pada tahap ini meliputi:

a) Mengembangkan ichtisar proyek menjadi penyelesaian akhir.

b) Memeriksa masalah teknis.,

c) Meminta persetujuan dari klien,. d) Mempersiapkan rancangan sketsa/pra rancangan, termasuk taksiran biaya, rancangan terinci, spesifikasi dan jadwal, daftar kuantitas, taksiran biaya akhir, program pelaksanaan pendahuluan termasuk jadwal waktu.

3. Tahap pelelangan(tender)menunjuk kontraktor bangunan, atau sejumlah kontraktor yang akan melaksanakan konstruksi. Kegiatan pada tahap ini untuk mendapatkan penawaran dari para kontraktor untuk pembangunan gedung dan untuk menyerahkan kontrak. Dalam tahap ini klien terkait kuat pada sebagian besar pengeluaran proyek, jadi prosedur serta proses harus di definisikan secara cermatdan ketat.

4. Tahap konstruksi atau tahap pelaksanaan pembangunan bertujuan membangun bangunan dalam batasan biaya dan waktu yang telah disepakati, mutu yang telah disyaratkan. Kegiatan dalam tahap ini adalah : rencanamengkoordinasi danmengendalikan sebagaimana mestinya. Kegiatannya adalah :

a) Mempersiapkan catatan pelaksanaan

b) Meneliti bangunan dengan cermat dan memperbaiki kerusakan

c) Menguji sifat kedap air bangunan

d) Memulai menguji dan menyesuaikan semua fasilitas

e) Mempersiapkan petunjuk operasi serta pedoman pemeliharaan

f) Melatih staf

Sedangkan menurut Istiawan

Dipohusodo (2003) dalam Suyatno 2010 tahapan konstruksi dibagi menjadi 5 tahap yaitu :

1. Tahap pengembangan konsep, adapun kegiatan yang dilakukan dalan tahap ini adalah melakukan survey pendahuluan dengan 
investigasi lapangan dimana proyek akan dilaksanakan. Hal ini akan mengungkapkan informasiinformasi yang sangat diperlukan dalam pembuatan konsep proyek. Seperti misalnya informasi mengenai upah tenaga kerja setempat, harga material, perizinan pemerintah setempat, kemampuan penyedia jasa setempat baik kontraktor maupun konsultan, informasi mengenai iklim disekitar lokasi proyek yang digunakan untuk mengantisipasi kendala yang dapat diakibatkan oleh cuaca dan lain sebagainya.

2. Tahap perencanaan, adapun kegiatan yang dilakukan adalah pengajuan proposal, survei lanjutan, pembuatan desain awal/sketsa rencana (preliminary design) dan perancangan detail (detail design), keempat kegiatan ini tidak dapat dipisahkan satu sama lain karena hasil kegiatan pertama akan berpengaruh pada kegiatan kedua dan selanjutnya. Tujuan dari tahap ini sebenarnya untuk mendapatkan rencana kerjafinal yang memuat pengelompokan pekerjaan dan kegiatan secara terperinci. Adapun sasaran pokok rencana kerja final adalah :

a) Dengan menggunakan sebagai pedoman pelaksanaan pekerjaan maka akandidapat harga kontrak konstruksi dan material yang lebih pasti, bernilai tetap dan bersaing, sehingga tidak akan melewati batas anggaran yang tersedia.

b) Pekerjaan akan dapat diselesaikan sesuai dengan kualitas dan dalam rentang waktu seperti yang telah direncanakan atau ditetapkan.

3. Tahap pelelangan, kegiatan yang dilakukan adalah kegiatan administrasi untuk pelelangan sampai dengan terpilihnya pemenang lelang.

4. Tahap Pelaksanaan Konstruksi, dalam tahap ini adapun kegiatan yang dilakukan antara lain persiapan lapangan, pelaksanaan konstruksi fisik proyek sampai dengan selesainya konstruksi itu sendiri. Salah satu kegiatan yang cukup penting pada saat pelaksanaan konstruksi fisik adalahkegiatan pengendalian biaya dan jadwal konstruksi, untuk pengendalian biaya konstruksi hal-hal yang harus diperhatikan adalah alokasi biaya untuk sumber daya proyek mulai dari tenaga kerja, peralatan sampai dengan material konstruksi, sedangkan pengendalian jadwal diupayakan agar setiap kegiatan dalam proyek berjalan sesuai dengan yang direncanakan, dalam hal ini semua pihak yang terlibat diharapkan bisa menggunakan berbagai sumber daya yang dimiliki agar tujuan proyek tercapai dengan baik.

5. Tahap pengoperasian, setelah konstruksi fisik selesai maka penyedia jasa akanmenyerahkannya kepada pengguna jasa untuk dioperasikan, dalam tahap ini penyedia jasa masih memiliki tanggung jawab untuk memelihara bangunan tersebut sesuai dengan perjanjian.

\section{F. Tahapan Pelaksanaan}

Menurut A.D. Austendan R.H. Neale (2001)dalam Suyatno 2010, kegiatan yang dilakukan dalam tahapan ini adalah merencanakan, mengkoordinasi, dan mengendalikan semua operasional 
dilapangan.Perencanaan dan pengendalian proyek secara umum meliputi 4 macam :

1. Perencanaan dan pengendalian jadwal waktu proyek

2. Perencanaan dan pengendalian organisasi lapangan

3. Perencanaan dan pengendalian tenaga kerja

4. Perencanaan dan pengendalian peralatan dan material

Koordinasi seluruh operasi dilapangan meliputi 2 macam :

1. Mengkoordinasi seluruh kegiatan pembangunan, baik untuk bangunan sementara maupun bangunan permanen, serta semua fasilitas dan perlengkapan yang terpasang.

2. Mengkoordinasi para sub kontraktorSedangkan masalahmasalah yang berpengaruh terhadap waktu pelaksanaan konstruksi lebih banyak disebabkan oleh mekanisme penyelenggaraan seperti keterlambatan pengadaan material dan peralatan, keterlambatan jadwal perencanaan, perubahan- perubahan pekerjaan selama berlangsungnya konstruksi, kelayakan jadwal konstruksi, masalah-masalah produktifitas, peraturan-peraturan dari pemerintah mengenai keamanan perencanaan dan metode konstruksi, dampak lingkungan, kebijakan dibidang ketenaga kerjaan dan lain sebagainya.

G. Keterikatan Biaya, Waktu, dan Kualitas

Menurut Istiwan Dipohusodo (2003)dalam Suyatno 2010, sebagaimana layaknya pelayananjasa, ketentuan mengenai biaya, mutu dan waktu penyelesaian konstruksi sudah diikat dalam kontrak dan ditetapkan sebelum pelaksanaan konstruksi dimulai. Apabila dalam proses konstruksi terjadi penyimpangan kualitas hasil pekerjaan, baik disengaja atau tidak, risiko yang harus ditanggung tidak kecil. Cara memperbaiki bangunan yang tidak sesuai dengan spesifikasi harus dibongkar, kemudian dibangun ulang. Dipihak lain upaya untuk memperbaiki tidak dapat mengubah kesepakatan pembiayaan dan jangka waktu pelaksanaan. Dengan demikian faktor biaya, waktu dan kualitas dalam proses konstruksi merupakan kesepakatan mutlak yang tidak bisa ditawar-tawar lagi dan ketiganya saling tergantung dan berpengaruh secara ketat.

\section{METODE PENELITAN}

A. Lokasi dan Waktu Penelitian.

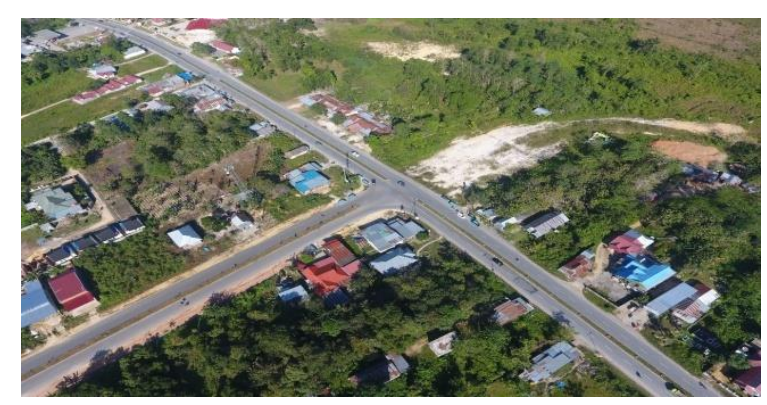

( Gambar. 3.1 Site Plant Jalan Lingkar Kota Kendari )

( Sumber : Site Plant 2017 ) 
Kondisi Geografis Lokasi pengambilan data

dilakukan pada pekerjaan bangunan jalan

lingkar Kota Kendari II (lanjutan), Provinsi

Sulawesi Tenggara.Jalan Poros Andoolo -

Konda. Penelitian ini mengambil lokasi pada

Proyek Pembangunan jalan lingkar Kota

Kendari II (lanjutan) yang terletak di Nanga-
Nanga, Kelurahan Baruga, Kecamatan

Baruga, Kota Kendari, Provinsi Sulawesi

Tenggara.

\section{Waktu Penelitian}

Penelitian tugas akhir ini telah dilakukan pada bulan September 2017 sampai Februari 2018dilihat pada Tabel 3.1

\section{TIME SCHEDULE PENELITIAN}

Waktu Pelaksanaan : Oktober 2017 - Februari 2018

\begin{tabular}{|c|c|c|c|c|c|c|c|c|c|c|c|c|c|c|c|c|c|c|c|c|c|}
\hline \multirow{2}{*}{ KEGIATAN } & \multirow{2}{*}{ Minggu } & \multicolumn{4}{|c|}{ Oktober 2017} & \multicolumn{8}{|c|}{ November 2017 Desember 2017 } & \multicolumn{4}{|c|}{ Januari 2018} & \multicolumn{4}{|c|}{ Februari 2018} \\
\hline & & 1 & 2 & 3 & 4 & 1 & 2 & 3 & 4 & 1 & 2 & 3 & 4 & 1 & 2 & 3 & 4 & 1 & 2 & 3 & 4 \\
\hline WAKTU PELAKSANAAN PENELITIAN & 18 & & & & & & & & & & & & & & & & & & & & \\
\hline 1. PROPOSAL PENELITIAN & 10 & & & & & & & & & & & & & & & & & & & & \\
\hline 1.1 Persiapan Proposal Penelitian & 2 & & & & & & & & & & & & & & & & & & & & \\
\hline 1.2 Pengajuan Judul Proposal Penelitian & 1 & & & & & & & & & & & & & & & & & & & & \\
\hline 1.3 Proses Perizïnan & 1 & & & & & & & & & & & & & & & & & & & & \\
\hline 1.4 Penyusunan Proposal Penelitian & 4 & & & & & & & & & & & & & & & & & & & & \\
\hline 1.5 Konsultasi Ke Pembimbing & 2 & & & & & & & & & & & & & & & & & & & & \\
\hline 1.6 Seminar Proposal Penelitian & 1 & & & & & & & & & & & & & & & & & & & & \\
\hline 1.7 Perbaikan Proposal Penelitian & 3 & & & & & & & & & & & & & & & & & & & & \\
\hline 2. HASIL & 23 & & & & & & & & & & & & & & & & & & & & \\
\hline 2.1 Pengambilan Data Proyek & 2 & & & & & & & & & & & & & & & & & & & & \\
\hline 2.2 Analisis Data Dan Pembahasan & 14 & & & & & & & & & & & & & & & & & & & & \\
\hline 2.3 Konsultasi Ke Pembimbing & 3 & & & & & & & & & & & & & & & & & & & & \\
\hline 2.4 Seminar Hasil & 1 & & & & & & & & & & & & & & & & & & & & \\
\hline 2.5 Perbaikan Seminar Hasil & 2 & & & & & & & & & & & & & & & & & & & & \\
\hline 2.6 Ujlan Akhir & 1 & & & & & & & & & & & & & & & & & & & & \\
\hline
\end{tabular}

\section{B. Populasi dan Sampel}

\section{Populasi}

Populasiadalah wilayah generalisasi yang terdiri atas obyek atau subyek yang mempunyai kualitas dan karakteristik tertentu yang ditetapkan peneliti untuk dipelajari dan ditarik kesimpulanya. Maka dari penjelasan diatas penulis menetapkan populasi penelitian ini meliputi: 
1) Tim Pembebasan Lahan yaitu dari Pihak Biro Pemerintahan Prov. Sulawesi Tenggara dengan jumlah 8 orang .

2) Pengguna anggaran (Owner), yaitu Pihak Kontraktor atau Pihak Pelaksana Pekerjaan dengan jumlah 4 orang.

3) Rekanan (Kontraktor) serta tenaga kerja yaitu Pihak Direksi dari Dinas Penyedia Barang Dan Jasa dengan jumlah 10 orang.

4) Konsultan yaitu Konsultan Perencanaan 1 orang.

5) Konsultan Pengawas yaitu Konsultan Pengawas Lapangan minimal 7 orang.

Dari beberapa populasi yang diambil hanya pada pihak-pihak yang bersangkutan pada PembangunanJalan Lingkar Kota Kendari II (lanjutan) Provinsi Sulawesi Tenggarahingga mencapai 30 sampel.

\section{Sampel}

Teknik sampling untuk memberikan peluang yang sama pada setiap anggota populasi untuk dipilih menjadi anggota sampel, adapun teknik pengambilan sample dengan cara probability sampling sebagai berikut :

a) Simple RandomSampling (Sampling Acak), dikatakan Simple (sederhana), karena pengambilan sample anggota populasi dilakukan secara acak tanpa memperhatikan strata yang ada. Cara demikian ini dilakukan bila anggota populasi dianggap homogen.

b) Proportionate Stratified Random Sampling, Teknik ini digunakan apabila populasi mempunyai anggota/unsur yang tidak homogen dan berstrata secara proposional.

c) Pengambilan sampel dari beberapa populasi yaitu:

1) Tim Pembebasan Lahan terdiri dari 8 orang

2) Pengguna anggaran (Owner) terdiri dari 4 orang

3) Rekanan (Kontraktor) serta tenaga kerja terdiri dari 10 orang
4) Konsultan terdiri dari 1 orang

5) Konsultan Pengawas terdiri dari 7 orang

\section{Variabel Penelitian}

Variabel pada penelitian ini meliputi Pelaksanaan proyek (Y), sebelum dilaksanakan suatu pekerjaan terlebih dahulu ada kontrak pekerjaan proyek dan gambar rencana pekerjaan. Pembebasan lahan (X1), sebelum di laksanakan pekerjaan terlebih dahulu di ukur batas proyek pekerjaan dengan lahan warga. Pada saat pelaksanaan pekerjaan, masalah ketersediaanAnggaran (X2), sesuai dengan RAB proyek yang akan dikerja. Kondisi geografis (X3), sebelum dilaksanakan pekerjaan dilakukan pengukuran letak lokasi pekerjaan, disertai dengan foto dokumentasi.

\section{Sumber Data dan Teknik Pengumpulan Data}

1. Sumber Data

a) Data Primer

Data Primer merupakan data yang didapat secara langsung dari sumbernya atau yang diamati. Data primer dalam penelitian ini yaitu: Data koesioner yang meliputi Jawabanrespondenterhadap pihak pihak yang terlibat dalam proyekjalan lingkar Kota Kendari II (lanjutan).

\section{b) Data Skunder}

Data sekunder meliputi :

1) Rencana Anggaran Biaya

2) Gambar Rencana

\section{Teknik Pengumpulan Data}

Metode pengumpulan data dalam penelitian ini adalah observasi lapangan dengan cara melakukan survey lapangan pada lokasi penelitian, untuk mendukung data-data penelitian, sehingga mendapakan keterangan-keterangan yang berhubungan dengan pelaksanaan proyek pembangunan jalan lingkar kota Kendari II. kemudian memberikan pertanyaan melalui kuisioner kepada seluruh pihak yang terlibat dalam pelaksanaan kegiatan yang di teliti, lalu 
dikumpulkan semua kuisioner untuk dilakukan rekapitulasi dari jawaban responden, Selain itu data sekunder juga di peroleh melalui dokumen kontrak, pelaksana kegiatan serta, Tim Pembebasan Lahan dari Dinas PU Provinsi Sulawesi Tenggara serta Pejabat Pelaksana Teknis Kegiatan (PPTK). Provonsi Sulawesi Tenggara. Persepsi responden dapat diurutkan menjadi: tidak berpengaruh, agak berpengaruh, berpengaruh dan sangat berpengaruh Kalau tidak berpengaruhdiberi nilai 0 ( nol ), agak berpengaruh diberi nilai 1 ( satu ), berpengaruhdiberi nilai 2 ( dua ), sangat berpengaruhdiberi nilai 3 ( tiga ).

\section{E. Teknik Analisis Data}

1. Pembebasan lahan yaituPekerjaan proyek jalan lingkar kota kendari II, pada saat pelaksanaan pekerjaan ada namanya ganti rugi yang dilakukan dari pihak pemerintah kepada masyarakat, apabila ada lahan masyarakat yang lahannya terkena proyek tersebut.

2. Ketersediaan anggaran yaitu Pekerjaan proyek jalan lingkar kota kendari II, dengan panjang $38,15 \mathrm{~km}$, lebar 8 $\mathrm{m}$, dengan jumlah anggaran Rp. 2.607.981.000,00 hal ini sangat terbatas. Sehingga pihak kontraktor melaksanakan pekerjaan proyek sesuai volume yang ada.

3. Kondisi geografis yaitu Pekerjaan proyek jalan lingkar Kota Kendari II, ada gambar rencana dan item- item pekerjaan sebelum melaksanakan suatu pekerjaan proyek tersebut.

Untuk menentukan nilai rata-rata persepsi responden menggunakan rumus pada persamaan 3.1 berikut ini :

$$
X_{\text {rata }- \text { rata }}=\mathrm{I}=\frac{1}{N} \sum_{i=1}^{n} \mathrm{x}_{i} \ldots \ldots \ldots .
$$
(3.1)

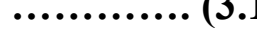

Dengan :

$\mathrm{I}=$ IndeksKepentingan

$\mathrm{X}_{\mathrm{i}}=$ frekuensi respon dari setiap persepsi

$$
\mathrm{N}=\text { jumlah data }
$$

\section{F. Definisi Operasional}

Adapun definisi operasional dalam penelitian ini adalah:

1) Pembebasan lahan (X1) menyediakan tanah dengan cara mengganti rugi yang layak dan adil kepada pihak yang berhak apabila tanah tersebut terkena lokasi pekerjaan proyek tersebut.

2) Ketersediaan Anggaran (X2)rencana anggaran biaya disesuaikan dengan volume pekerjaan yang akan di kerja.

3) Kondisigeografis (X3)merupakan keadaan dimana menggambarkan situasi atau aktivitas suatu tempat, wilayah atau daerah tersebut.

\section{G. Konsep Operasional}

Adapuntahapan-tahapankegiatan yangakan dilakukan dalam penelitian ini, disajikandalam bentukbaganalirberikut ini: 


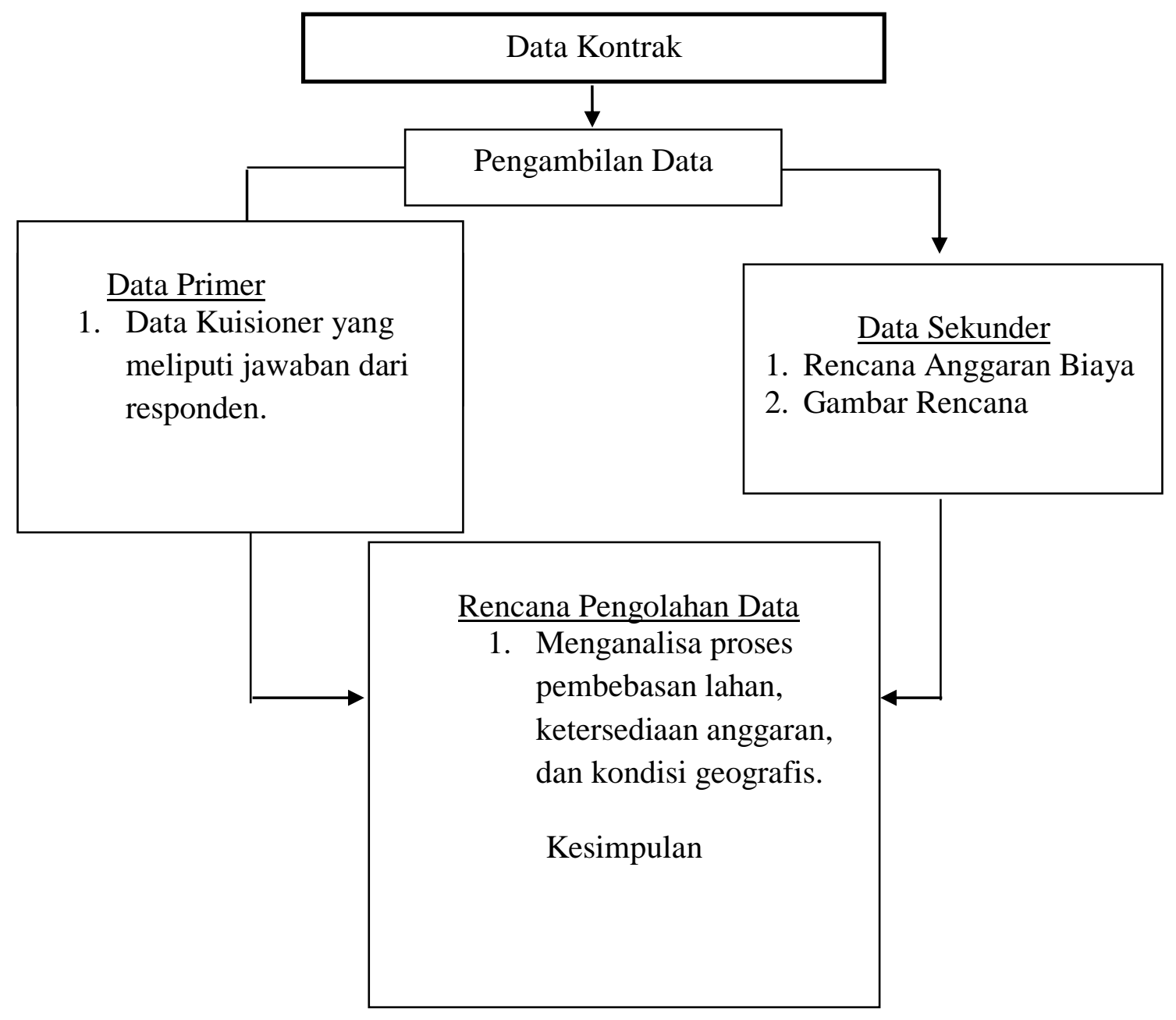

Gambar 3.2 : Bagan Alir Penelitian 


\section{HASIL DAN PEMBAHASAN}

\section{A. Pendapat Responden}

Hasil penelitian danpendapat responden yang terdiri dari 30 orang responden serta 3 pertanyaan yang kami berikan terhadap faktor yang mempengaruhipenyelesaianproyek

konstruksi jalan lingkar Kota Kendari II dapat di rekap dalam bentuk tabel adalah sebagai berikut:

Tabel 4.1 Pendapat Responden Terhadap Faktor yang mempengaruhi penyelesaian proyek jalan.

Faktor-faktor

yang

Tidak

Agak

Sangat

mempengaruhi

berpengaruh berpengaruh

No proyek

1. Pembebasan

1. Lahan

0

7

18

5

30

Ketersediaan

2. Anggaran

0

7

15

8

30

$\begin{array}{ll}\text { 3. } & \text { Kondisi } \\ \text { Geografis }\end{array}$

9

10

8

3

30

Sumber : Hasil Anlisis Data ( 2018 )

Dari presentasi nilai yang tertera diatas maka setiap kolam angka tabel di bawah ini dikalikan dengan angka yang telah tertera di atas Sehingga dimasukan dalam tabel presentase di bawah ini : Dengan menggunakan rumusperhitungan statistik: :

$$
1=\frac{7}{30} \times 100=23 \%
$$

$7=$ nilai rekapan pendapat responden

$1=$ Pembebasan lahan

$30=$ Jumlah responden

Tebel 4.2 Presentasi Jawaban Responden

$\begin{array}{lcccc}\begin{array}{l}\text { Faktor-faktor } \\ \text { yang } \\ \text { mempengaruhi } \\ \text { proyek }\end{array} & \begin{array}{c}\text { Tidak } \\ \text { berpengaruh }\end{array} & \begin{array}{c}\text { Agak } \\ \text { berpengaruh }\end{array} & \begin{array}{c}\text { Sangat } \\ \text { Berpengaruh }\end{array} & \begin{array}{c}\text { berpengaruh } \\ \text { NO }\end{array} \\ \begin{array}{l}\text { Pembebasan } \\ \text { Lahan }\end{array} & 0 & \% & \% & \% \\ \end{array}$



2. Ketersediaa
0
23
50
27
3. $\begin{aligned} & \text { Kondisi } \\ & \text { Geografis }\end{aligned}$
30
33
27
10

Sumber : Hasil Analisis data ( 2018 )

Dari tabel presentasi di atas maka didapatkan item yang sangat berpengaruh dan tidak berpengaruh terhadap penyelesaian proyek Bina Marga. Dengan hasil peresentasi di atas, untuk memudahkan untuk penyelesaian dalam mencapai nilai mean (rata-rata) maka kami peneliti mengunakan Microsoft Office Excel 2007. Angka mean didapat dari jumlah keseluruhan data dalam seitap item di bagi dengan banyak data dalam satu item, Sehingga dapat ditulis dalam tabel dibawah ini.

Untuk tabel angka ranking yang terterah di bawah ini di peroleh dari hasil perhitungan nilai mean yang ada, maka direngkingkan sesuai dengan hasil rata-rata dari butir satu sampai dengan 3 . Angka perengkingan yang ada pada tabel di bawah ini, terdiri dari ranking 1 sampai dengan ranking 3 yang di hasilkan berdasarkan nilai rata-tata tertinggi sampai yang terendah. Untuk nilai rata-rata sama maka memiliki nelai ranking yang sama pula.

SebagaicontohperhitunganNilai ratarata(Mean)makadicariindekskepentingan yaitu:

Dari tabel di atas dapat diketahui urutan ranking yang paling berpengaruh dari tiga variabel terhadap pelaksanaan pekerjaan jalan lingkar Kota Kendari II yaitu sebagai berikut :

Anggaran

Ranking 1 adalah Ketersediaan

Ranking 2 adalah Pembebasan Lahan Ranking 3 adalah Kondisi Geografis Angka tersebut dapat diuraikan sebagai berikut :

$0 \times 0$ = jawaban responden; nilai $0=$ skor tidak berpengaruh

$7 \times 1=$ jawaban responden; nilai $1=$ skor agak berpengaruh

18x $2=$ jawaban responden; nilai $2=$ skor berpengaruh

$5 \times 3=$ jawaban responden ; nilai $3=$ skor sangat berpengaruh 
Tabel 4.3 Hasil Analisis Data RankingFaktorpendapat responden terhadap faktor yang mempengaruhi penyelesaian proyek jalan

No Faktor Penyebab Keterlambatan

1.

Pembebasan Lahan

Ketersediaan Anggaran

2.

3.

Kondisi Geografis

Sumber: Hasil Analisis Data (2018)

Dari nilai mean (rata-rata) dan nilai ranking yang ada pada tabel di atas dapat diperjelas dengan tabel bobot (\%). Untuk tabel di bawah ini, angka bobot diperoleh dari nilai mean. Setiap itemnya dikali 100\% lalu

Tabel 4.4 Hasil Analisis Data Rekapan Pembobotan(\%)

\section{Faktor Penyebap Keterlambatan}

No

Pembebasan Lahan

1.

2.

Ketersediaan Anggaran

Kondisi Geografis 5,13 .

\section{Mean Ranking}

1,93

2

2.03

1

1,17

hasilnya dibagi dengan jumlah total keseluruhan nilai mean dari butir 1-3. Yaitu dengan di jumlahkan $1,93+2,03+1,17=$

\section{Bobot (\%) Ranking}

37,6

2

3.

22,8

3

Sumber :Hasil Analisis Data ( 2018 )

A. Pembahasan

1. Ketersediaan Anggaran 
Item ini dianggap sangat berpengaruh oleh responden karena pada item ini para pekerja proyek (kontraktor)akan banyak mengalami kendala dilapangan. Para responden berpendapat bahwa faktor uang yang membuat segala proses kegiatan di lapangan akan berpengaruh dengan proses pelaksanaan pekerjaan dan mengakibatkan hambatan dalam pelaksanaannya, dalam penyelesaian sebuah proyek seorang kontraktor akan mengalami kendala apabila uangnya tidak ada, item lain dalampelaksananan proyek akan ikut terhambat apabila uang tidak siap misalnya alat,material karyawan dan lain sebagainya, dengan demikian pelaksanaan sebuah pekerjaan proyek akan terlambat. Begitu pula sebaliknya apabila uang semua siap maka pekerjaan akan terselesaikan sesuai dengan waktu yang di tentukan di konrak.

Tabel 4.5 Hasil Analisis Data Dinas PU.Prov.Sultra

\begin{tabular}{llcllll}
$\begin{array}{c}\text { Nama Ruas } \\
\text { Jalan }\end{array}$ & \multicolumn{1}{c}{ Pelaksana } & Anggaran & $\begin{array}{c}\text { Nomor } \\
\text { Kontrak }\end{array}$ & Mulai & \multicolumn{1}{c}{ Selesai } & PPTK \\
Pembangunan & PT. & $\mathbf{2 . 6 0 7 . 9 8 1 . 0 0 0}$ & $602 / 331 /$ PU- & Tgl, 14 Juni & Tgl,12 \\
Jalan Lingkar & MAHAPUTRI & & BM/VI/2016. & 2016 & Desember & \\
Kota Kendari & UTAMA & & Tanggal, 14 & 2016 \\
II & & & Juni 2016 & &
\end{tabular}

Sumber : Hasil Analisis Data Dinas PU.Prov.Sultra (2018)

\section{Pembebasan Lahan}

Para responden berpendapat bahwa item ini berpengaruh terhadap penyelesaian proyek karena tanpa adanya kejelasan obyek atau lokasi pekerjaan proyek akanmengalami hambatan, pada item ini para kontraktor akan mengalami kendala dalam penyelesaian proyek. hal-hal yang membuat terkendala dalam item ini yaitu misalnya seorang kontraktor belum adanya kejelasan terhadap lahan atau lokasi tempat proyek.

Tabel 4.6Pendapat Responden Terhadap Faktor yang mempengaruhi penyelesaian proyek jalan.

Faktor-faktor

yang Tidak Agak Sangat

No mempengaruhi berpengaruh berpengaruh proyek

Berpengaruh berpengaruh Jumlah Pembebasan
Lahan

0

7

18 
Tabel 4.7Presentase Jawaban Responden

Faktor-faktor yang

NO mempengaruhi proyek

1. Pembebasan Lahan
Tidak

berpengaruh berpengaruh
Berpengaruh

60
60
Sangat

berpengaruh

Sumber : Hasil Analisis Data ( 2018 )

\section{Kondisi Geografis}

Item ini dianggap tidak terlalu berpengaruh karena dalam perencanaan suatu pekerjaan sudah tentu memperhitungkan kondisi geografisnya apakah lokasi itu perbukitan, lembah, rawah ataupun yang lainnya. Dalam
23 perencanaan sudah semua item memperhitungkan besaran anggaran yang akan dihabiskan, namun yang menjadi masalah bilamana anggaran tidak tersedia. Berikut tabel rekapan kuisioner untuk analisis faktor pelaksanaan :

Tabel 4.8Hasil Analisa Data Rekapan Kuisioner Untuk Analisis Faktor Pelaksanaan :

\begin{tabular}{|c|c|c|c|}
\hline \multirow{2}{*}{ No } & \multicolumn{3}{|c|}{ 3 Faktor Proses Pelaksanaan } \\
\cline { 2 - 4 } & $\mathbf{X 1}$ & $\mathbf{X 2}$ & $\mathbf{X 3}$ \\
\hline 1 & 1 & 3 & 2 \\
\hline 2 & 1 & 2 & 2 \\
\hline 3 & 2 & 3 & 2 \\
\hline 4 & 1 & 3 & 2 \\
\hline 5 & 2 & 3 & 2 \\
\hline 6 & 1 & 3 & 0 \\
\hline 7 & 2 & 3 & 2 \\
\hline 8 & 2 & 3 & 2 \\
\hline 9 & 1 & 2 & 2 \\
\hline 10 & 3 & 2 & \\
\hline
\end{tabular}




\begin{tabular}{|c|c|c|c|}
\hline 11 & 3 & 3 & 0 \\
\hline 12 & 1 & 2 & 2 \\
\hline 13 & 3 & 3 & 2 \\
\hline 14 & 3 & 2 & 0 \\
\hline 15 & 3 & 3 & 2 \\
\hline 16 & 1 & 3 & 2 \\
\hline 17 & 2 & 3 & 0 \\
\hline 18 & 1 & 3 & 3 \\
\hline 19 & 3 & 2 & 2 \\
\hline 20 & 1 & 2 & 0 \\
\hline 21 & 1 & 2 & 2 \\
\hline NO & \multicolumn{3}{|c|}{3 Faktor Proses Pelaksanaan } \\
\hline & $\mathbf{X 1}$ & $\mathbf{X} 2$ & $\mathbf{X 3}$ \\
\hline 22 & 1 & 3 & 0 \\
\hline 23 & 2 & 3 & 2 \\
\hline 24 & 2 & 3 & 0 \\
\hline 25 & 1 & 2 & 3 \\
\hline 26 & 2 & 3 & 1 \\
\hline 27 & 1 & 3 & 2 \\
\hline 28 & 1 & 3 & 2 \\
\hline 29 & 2 & 2 & 1 \\
\hline 30 & 1 & 3 & 2 \\
\hline
\end{tabular}

Sumber: Hasil Analisis Data ( 2018 ) 
Keterangan :

X1 = Pembebasan Lahan

$X 2=$ Ketersediaan Anggaran

X3 = Kondisi Geografis

Tabel 4.9 Pendapat Responden Terhadap Faktor yang mempengaruhi penyelesaian proyek jalan.

Faktor-faktor

yang Tidak Agak Sangat

No mempengaruhi berpengaruh berpengaruh Berpengaruh berpengaruh Jumlah

$\begin{array}{llllll}\text { Kondisi } & 9 & 10 & 8 & 3 & 30 \\ \text { Geografis } & 9 & 10 & \end{array}$

Sumber : Hasil Anlisis Data ( 2018 )

Tebel 4.1.0 Presentasi Jawaban Responden

Faktor-faktor yang mempengaruhi

NO proyek
Tidak berpengaruh berpengaruh
Agak

Berpengaruh
Sangat

berpengaruh

1. Kondisi Geografis

30

33

27

10

Sumber : Hasil Analisis data ( 2018 ) 
Dari tabel 4.8 yang memiliki jumlah 3 faktor yang tertera masing- masing terdiri dari 30 hasil responden dan dapat di jelaskan pada tabel-tabel berikutnya yang ada dibawah ini sesuai dengan output hasil olahan SPSS (analisis faktor):

Tabel: 4.1.1Hasil Analisis Data Output Olahan SPSS

\begin{tabular}{|l|c|c|}
\hline \multicolumn{1}{|c|}{ Faktor Proses Pelaksanaan } & Initial & Extraction \\
\hline Pembebasan Lahan & 1.000 & 68,5 \\
Ketersediaan Anggaran & 1.000 & 93,3 \\
Kondisi Geografis & 1.000 & 61,8 \\
\hline
\end{tabular}

Sumber : Hasil Analisis Data ( 2018 )

Dari tabel 4.1.1 merupakan hasilolahan data outputmenggunakan SPSS, sehingga nilai Communalities merupakan nilai yang menunjukkan kontribusi variabel tersebut terhadap faktor yang terbentuk.Dapat juga didefinisikan sebagai besaran nilai varians (dalam persentase) suatu variabel yang dapat dijelaskan oleh faktor yang terbentuk.Nilai communalities ini sama pengertiannya dengan nilai koefisien determinasi (pada model regresi).

- Pada tabel 4.1.1 nilai communalities variabel Pembebasan Lahan (X1) $=68,5 \%$; ini berarti sebesar 68,5\% varians dari variabel Pembebasan Lahan dapat dijelaskan oleh faktor yang terbentuk.
- Untuk variabel Ketersediaan Anggaran, nilai communalities $=93,3 \%$. Hal ini berarti sekitar 93,3\% varians dari Ketersediaan Anggaran dijelaskan oleh faktor yang terbentuk. Demikian seterusnya dengan variabel lainnya.

- Untuk variabel Kondisi Geografis, nilai communalities $=61,8 \%$. Hal ini berarti sekitar $61,8 \%$ varians dari Kondisi Geografis oleh faktor yang terbentuk.

- Semakin besar communalitiessebuah variabel,berarti semakin erat hubungannya dengan faktor yang terbentuk. 
Tabel: 4.1.2Hasil Analisis Data Total Variance Explained

\begin{tabular}{|c|r|r|r|r|r|l|}
\hline \multirow{2}{*}{ Component } & \multicolumn{3}{|c|}{ Initial Eigenvalues } & \multicolumn{3}{|c|}{$\begin{array}{c}\text { Extraction Sums of Squared } \\
\text { Loadings }\end{array}$} \\
\cline { 2 - 7 } & Total & $\begin{array}{r}\text { \% of } \\
\text { Variance }\end{array}$ & Cumulative \% & Total & $\begin{array}{c}\text { \% of } \\
\text { Variance }\end{array}$ & Cumulative \% \\
\hline 1 & 1.236 & 41.189 & 41.189 & 1.236 & 41.189 & 41.189 \\
2 & 1.000 & 33.333 & 74.523 & 1.000 & 33.333 & 74.523 \\
3 & 76,4 & 25.477 & 100.000 & & & \\
\hline
\end{tabular}

Sumber : Hasil Analisis Data ( 2018 )

Berdasarkan tabel di atas ada beberapa hal yang dapat diketahui:

1.) Nilai eigenvalues; yang menunjukkan jumlah variabel yang menjadi anggota suatu faktor.

2.) Besaran varians yang dapat dijelaskan oleh faktor dengan sejumlah variabel pembentuknya.

3.) Jumlah faktor yang dapat terbentuk oleh sejumlah variabel yang dimiliki.

4.) Setelah dilakukan ekstraksi, tampak dalam tabel 4.1.2 bahwa faktor yang terbentuk sebanyak 2 faktor, dengan masing-masing mempunyai nilai eigenvalues 1,236 dan 1.000 . sesuai dengan defenisi eigenvalues, berarti kita dapat mengatakan bahwa faktor1 beranggotakan 1.236 variabel dan faktor-2 beranggotakan 1.000 variabel (faktor yang mempunyai nilai eigenvalues $<1$, berarti tidak mempunyai anggota variabel pembentuk faktor).

5.) Tabel 4.1.2 menunjukkan adanya 3 component (variabel) yang dimasukkan dalam analisis faktor dengan masing-masing variabel memiliki variansi 1 , maka total varians adalah $3 \times 1=3$.

6.) Sesuai dengan jumlah faktor yang terbentuk dan jumlah variansi masing-masing variabel yang diketahui, selanjutnya dapat dijelaskan oleh masing-masing faktor maupun oleh keseluruhan faktor yang terbentuk (baik sebelum dirotasi dan setelah dirotasi).

- Variansfactor-1:(1,236/3) x $100 \%$ $=41,2 \%$

- Variansfactor-2 : (1/3) $\times 100 \%=$ $33.333 \%$

Artinya bahwa sebesar $44,567 \%$ variansdari variabilitas pembentuk faktor-1 dapat dijelaskan faktor tersebut, dan sebesar $41,2 \%$ varians dari variabilitas pembentuk faktor ke dua dapat dijelaskan oleh faktor tersebut. Sedangkan total ketiga faktor tersebut akan mampu menjelaskan $74.533 \%$ (faktot-1 + faktor-2 ) dari variabilitas ke-tiga variabel asli tersebut. 
Selain dari tabel Total Varians, yang menjelaskan dasar perhitungan dalam menentukan jumlah faktor, untuk melihat berapa jumlah faktor yang tebentuk dapat pula dilihat pada grafik :

Scree Plot

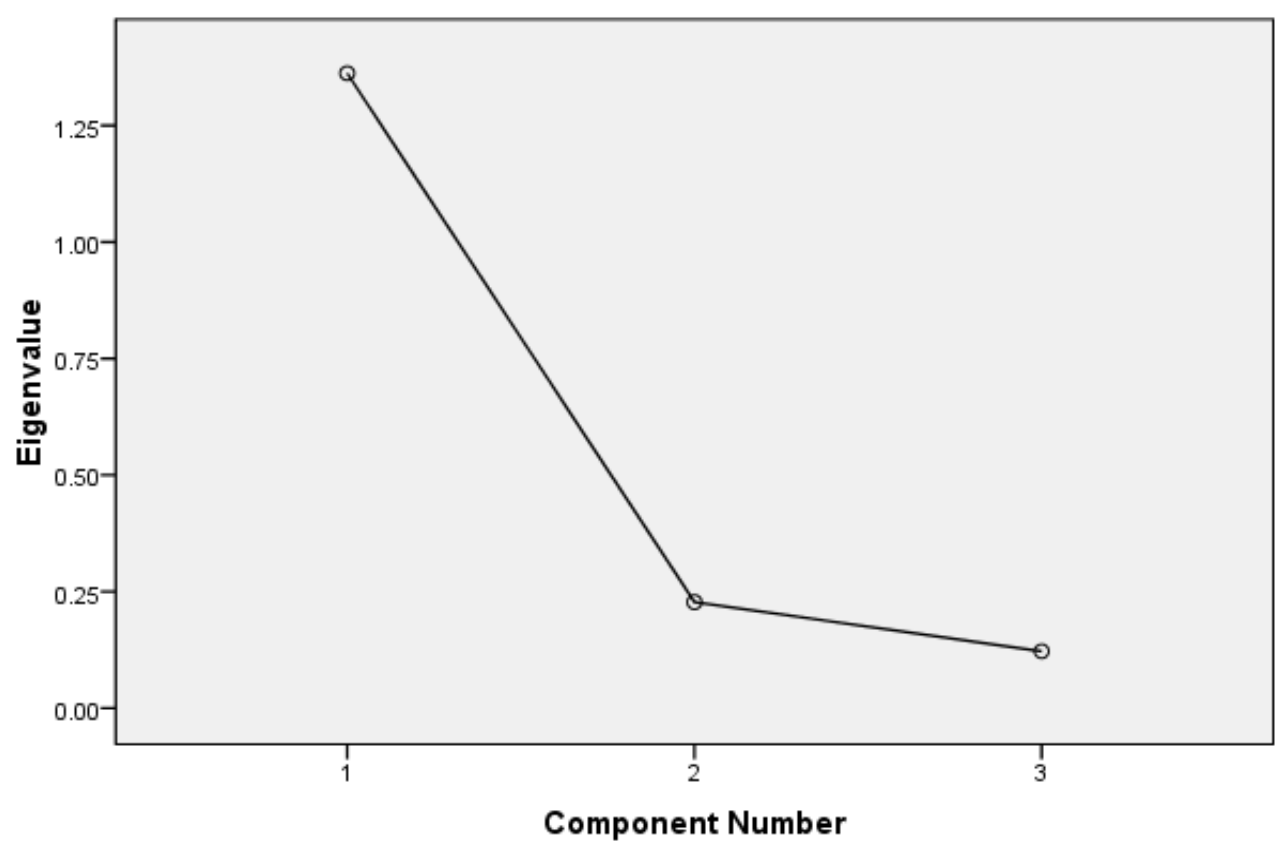

Gambar 4.1 Grafik Total Varians

Sumber : Hasil Analisa Data ( 2018 )

Nilai batas eigenvalues pembentuk faktor adalah 1 apabila kurang dari 1 berarti tidak terdapat variabel pembentuk faktor.Dengan demikian, dari grafik tersebut tampak bahwa ada 2 faktor yang terbentuk. Hal ini berarti sama dengan hasil pendefinisian sebelumnya. 
Tabel: 4.1.3Hasil Analisis Data Component Matrix ${ }^{a}$

Component Matrix ${ }^{a}$

\begin{tabular}{|l|c|c|}
\hline \multirow{2}{*}{ Faktor Proses Pelaksanaan } & \multicolumn{2}{|c|}{ Component } \\
& 1 & 2 \\
\cline { 2 - 3 } & 71,4 & $-41,8$ \\
\hline Pembebasan Lahan & 0,329 & 0,908 \\
Ketersediaan Anggaran & $-78,6$ & 00,0 \\
\hline
\end{tabular}

Sumber : Hasil Analisa Data ( 2018 )

\section{a) 2 components extracted.}

Tabel Component Matrix4.1.3 menunjukkan nilai loading factor masing-masing variabel terhadap faktor.Loading Factor adalah nilai yang menunjukkan hubungan (korelasi) suatu variabel terhadap faktor. Apabila suatu variabel mempunyai nilai loading factor terbesar pada faktor tertentu (dibanding faktor lainnya), maka variabel tersebut akan menjadi anggota atau pembentuk faktor tersebut. Nilai loading factor yang disarankan sebagai penentu komponen faktor yaitu setidaknya bernilai 0,7 (korelasi $\geq 0,7$ ). Hal ini sesuai dengan pendefenisian koefisien korelasi $\geq 0,7$ dikatakan bahwa adanya hubungan yang kuat antar variabel yang diteliti.
Dari tabel 4.1.3 dapat pula diketahui distribusi variabel terhadap 3 faktor yang terbentuk. Cara yang dilakukan untuk melihat distribusi variabel tersebut yaitu dengan membandingkan nilai loading factor suatu variabel pada faktor-faktor yang ada adalah sebagai berikut :

Korelasi variabel ketersediaan anggaran dengan faktor-2 pada komponen-1 adalah +0,329, berarti menunjukkan hubungan yang lemah. Sedangkan dengan faktor-2 komponen-2 mempunyai korelasi 0,908 berarti menunjukkan hubungan yang sangat kuat, dengan demikian, variabelketersediaan anggaran dimasukkan dalam komponen faktor-1.Hal ini berlaku pula untuk variabel lainnya sesuai urutan.

Dari beberapa faktor yang telah di analisis dapat di lihat pada gambar di bawah ini, untuk memastikan faktor-faktor tersebut masuk dalam komponen keberapa. 


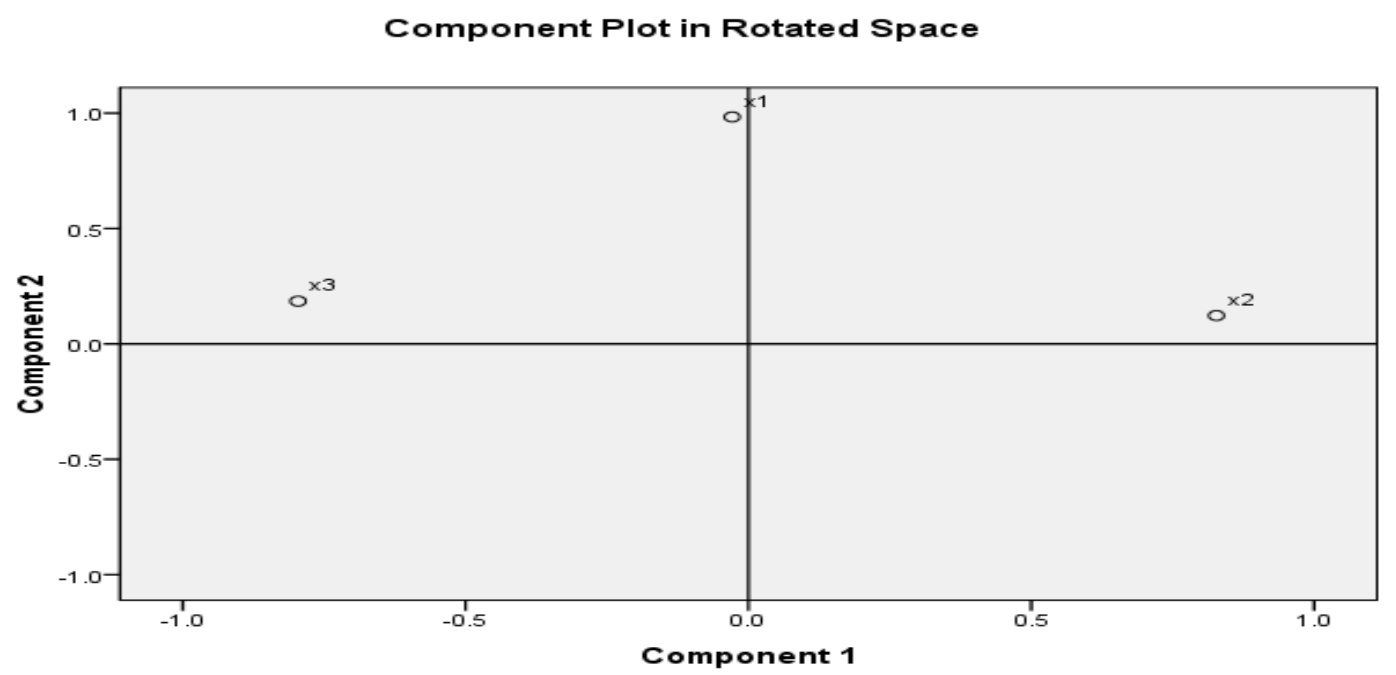

Gambar 4.2Grafik Componen Plot In Rotated Space

Sumber : Hasil Analisis Data ( 2018 )

Gambar 4.2 merupakan hasil dari analisis data yang menampilkan gambar letak ketiga variabel pada ketiga faktor yang ada. Perhatikan bahwa variabel - variabel yang terpisah dalam satu faktor akan terlihat berkejauhan antara ketiga faktor tersebut. Korelasi variabel ketersediaan anggaran dengan faktor-2 pada komponen-1 faktor-1. Faktor - faktor tersebut terdiri dari data, dimana laporan dari ketiga faktor tersebut dari rekapan responden melaporkan bagaimana masing- masing variabel terkait dengan faktor - faktor ini. Nilai pemuatan mewakili pentingnya variabel untuk komponen, ( koefisien korelasi yang diperoleh $\geq 0,7$ ).

menunjukan hubungan yang lemah. Sedangkan dengan faktor-2 komponen- 2 menunjukkan hubungan yang sangat kuat dengan demikian, variabel ketersediaan anggaran dimasukkan dalam komponen

\section{SIMPULAN DAN SARAN}

\section{A. Simpulan.}

Dari hasil penelitian dan analisis yang penulis lakukan dengan menggunakan rumus statistik memiliki simpulan sebagai berikut:

1. Hasil perhitungan analisis berdasarkan pembobotan yang 
masuk dalam kategori sangat berpengaruh terhadap penyebab proses penyelesaian proyek jalan lingkar Kota Kendari adalah Ketersediaan Anggaran 93,3\%,Pembebasan Lahan 68,5\%, Kondisi Geografis 61,8\%.

2. Korelasi variabel ketersediaan anggaran dengan faktor-2 pada komponen- 1 adalah $+0,329$, berarti menunjukkan hubungan yang lemah. Sedangkan dengan faktor-2 komponen-2 mempunyai korelasi 0,908 berarti menunjukkan hubungan yang sangat kuat, dengan demikianvariabelketersediaan anggaran dimasukkan dalam komponen faktor-1.

B.

\section{aran}

Saran untuk peneliti lebih lanjut:

1. Perlu dilakukan penelitian lebih lanjut yang terkait dengan faktor yang mempengaruhi proses pelaksanaan proyek, dengan mengkaji perbedaan pendapat antara kontraktor, konsultan dan direksi lapangan.

2. Dapat dilakukan penelitian lebihlanjut tentang hubungan faktor proses Pelaksanaan proyek dengan jumlah anggaran proyek atau dengan jumlah yang di kelolah oleh perusahaan dalam setiap tahunnya.

\section{DAFTARPUSTAKA}

AdoeM.L.DKK, 2013."KajianPenyebabKet erlambatanPelaksanaan

ProyekKonstuksiGedungDiKotaKupang.Jur nalTeknikSipil,Vol.II,No.2 “.

Ahyaria,2000.“ Pengendalian system Produksi, Buku 1 dan 2, BPEF, Yogyakarta".

AustenA.D. danR.H.Neale,2001.

"ManajemenProyekKonstruksiPedoman,
danProsedur,PPMdanPTPustakaBinamarga Pressindo,Jakarta “.

Anonim, Undang-Undang Republik Indonesia nomor 2tahun2017.

Tentang JasaKontruksi “.

Hidayat. A, 2004." Faktor-faktor

penyebabketerlambatan

diproyekkonstruksi ".

Furqon. 2004.

Statistikaterapanuntukpenelitian,CV,Alfabet a,Bandung ".

Hasan. H, 2016. " Jurnal Sipil Statik Vol.4 No.11 November 2016 (657-664) ISSN: 2337-6732".

http://e-journal.uajy.ac.id/4379/3/2TS12440. 2017, Pengertian Hambatan Proyek.

Ismiyati,2003.

"Statikadanaplikasinya,ProgramPascaSarjan aUnivessitas .Diponegoro “.

Istimawan.D,2003.

ManajemenProyekdanKonstruksijilid1dan2, KanNisius, Yogyakarta “.Imam. S, 1997, “ ManajemenProyek dari KonseptualsampaiOperasional, Erlangga,Jakarta “.

Jervis B.M., Levin P., 2000, “ Construction Proyect Schedulling, Mc

Graw Hill, New York ".

Karyanus, 2013.“ Faktor-Faktor

Menghambat Ekonomi

Teknik.Skripsi Universitas

Indonesia ".

Mustafid,2003.“

StatikaTerapan,ProgramPascaSarjanaUniver sitas Diponegoro.

Singaribun K. Efendi S, 2000. “ MetodePenelitian survei, PT.Pustaka LP3Indonesia,Jakarta ".

SinggihSantoso. 2001.“

CarakerjaProsesPerhitungandenganSPSS “.

Suharto. I,1995.

ManajemenProyekdariKonseptualsampaiden ganOprasional,Erlangga, Jakarta ".

Suyatno, TriVadliSetiaBudi,2001.“

Faktorpenyebabketerlambatanproyekkonstru ksiBangunanGedung “. 
Wijaya,2000. " Statikanonparametrik (AplikasiprogramSPSS),penerbitAlfa beta, Bandung “.

Wulfram, I.Ervianto, 2002.“ Manajemen ProyekKonstruksi, Penerbit Andi, Yogyakarta “. 
